\title{
THE CZECH AGRARIAN TRADE COMPARATIVE ADVANTAGES DISTRIBUTION BASED ON VALUE AND VOLUME APPROACH
}

\author{
Luboš Smutka1, Mansoor Maitah ${ }^{1}$, Miroslav Svatoš \\ ${ }^{1}$ Department of Economics, Faculty of Economics and Management, Czech University of Life Sciences Prague, \\ Kamýcká 129, 16500 Praha-Suchdol, Czech Republic
}

To link to this article: https://doi.org/10.11118/actaun201967061613

Received: 8. 2. 2018, Accepted: 5. 11. 2019

To cite this article: SMUTKA LUBOŠ, MAITAH MANSOOR, SVATOŠ MIROSLAV. 2019. The Czech Agrarian Trade Comparative Advantages Distribution Based on Value and Volume Approach. Acta Universitatis Agriculturae et Silviculturae Mendelianae Brunensis, 67(6): 1613-1625.

\begin{abstract}
In the last two decades, the Czech agrarian trade has undergone a very significant transformation. It had been considerably influenced by several dynamically developing factors, which originate not only in the area of economics, but also within the political and social sphere.

The objective of this paper is to identify the roots of Czech agrarian trade competitiveness in relation to EU and non-EU countries. The results of comparative advantages analyses are discussed in relation to Czech agrarian trade nominal value and volume performance. The paper identifies the set of items when trade performance is induced by increasing volume (increasing exports in $\mathrm{kg}$ ) and the set of items when trade performance is induced by increasing unit value performance. To accomplish the above mentioned tasks, the following methods have been applied: The LFI, RCA and TBI indices, product mapping and logarithmic decomposition. Based on individual applied methods the analyzed paper provides the results. However, Czech agricultural trade does not have comparative advantages in general (both in relation to EU and also non-EU countries), there are existing bilateral comparative advantages in the case of individual export items (non-EU: CN04, CN17, CN01, CN24, CN12, CN19, CN11, CN13 and CN18; EU: CN10, CN24, CN01, CN12, CN15, CN04, CN22, CN11, CN17, CN03, CN16, $\mathrm{CN} 09, \mathrm{CN} 13$ and CN14). The problems of Czech comparative advantages development in relation to the EU are constantly decreasing volume performance and decreasing unit value. On the other hand, in relation to non-EU countries, the relationship between increasing volume and value performance is more balanced and the comparative advantages are related to quality and higher added value aspects.
\end{abstract}

Keywords: trade, volume, price value, coverage of imports by exports, Czech Republic, EU28, world, Non-EU countries

\section{INTRODUCTION}

Czech agrarian trade, has in the last two decades undergone a very substantial transformation (Lukas, 1998; Kennedy and Sonnier, 1997; Presova et al., 2008). It was significantly influenced by several dynamically developing factors, which originate not only in the area of economy, but also in the political and social sphere (Fuller et al., 2002). For the most part, its pattern was affected by a large number of factors connected with the entrance on the Czech Republic to the EU, and also by the direction of the Common Agricultural and Common Trade policies of the EU countries (Burianova and Belova, 2012; Smutka et al., 2015). With that being said, the agrarian trade was influenced by not only the reforms conducted on the EU level, but also by reforms realized on the level of national economics and national policies. Lastly, 
the agrarian trade was also affected by the market situation of Non-EU countries (Svatoš et al., 2013). Globalization of the world economy, including the agrarian and food markets is another important element that has influenced Czech agrarian trade (Svatoš, 2008). In this regard, it is necessary to emphasize the impact of multinational capital and foreign investments on shaping the current state of the Czech agrarian sector, especially the food industry. It is the large multinational companies, who to a great extent determine the direction of the Czech agrarian and food trade, and by their actions also influence the direction of the trend that the Czech agrarian market follows. An example of such a company is Phillip Morris, the parent company of Tabák Kutná Hora a.s. The Czech Agrarian trade has in the past few years experienced a very significant transformation process, which has influenced not only its territory, but also the commodity structure and to a great extent is also reflected in the structure of the Czech agrarian trade in the terms of degree of processing of the traded products (Burianova, 2011; Mezera and Pohlova, 2014). In addition, it is mainly the export commodity structure, which in the case of the Czech Republic, is of an extreme characteristics and does not correspond with the standards which are common in developed countries (Kancs and Ciaian, 2010). When it comes to the development in terms of volume and value of the Czech agro trade, it is the Czech Republic that has shown distinctive specifics compared to a number of other countries, especially within the EU market. The Czech agrarian export market is rather typical because of its high volume performance, but its unit value characteristic is low. While the volume of agricultural trade increased more than five times within the last sixteen years, the nominal value of trade increased only four times. Even though the export performance is amazing, its characteristics is questionable. The foundations of exports are items that have limited added value. Sometimes one might ask whether the export is really profitable, e.g. export of wheat (According to data provided by Agrarian chamber of the Czech Republic; despite of the fact that wheat trade is typical because of positive trade balance, in fact the whole economy performance could be considered as negative because of high cost of fertilizers necessary for wheat production.). The problem of Czech added value export performance is that Czech producers' have limited ability to export high processed products (Nagyova et al., 2018; Vozarova et al., 2015; Jambor, 2014; Mezera and Pohlova, 2014). Many research studies published in the past have criticized Czech export commodity structure (Bojnec et al., 2018; Jambor et al., 2016). The significant share of export performance is represented by non-processed items or semi-finalized items. Many items considered as finalized, do not represent high added value production e.g. mineral water, milk, bakery products etc. (Bojnec et al., 2017; Nowak et al., 2016) Czech exporters' competitiveness is not influenced by products' quality, but by its low price (Burianova, 2011; Burianova, 2012). The Czech agrarian export is induced by a constantly increasing volume of cheap production and very limited unit price development. Many export items have been suffering because of a limited share of added value in the final price (similar results can be seen in the case of especially new EU member countries (Jambor, 2014; Ferto, 2008; Ferto and Hubbard, 2003; Voyarova et al., 2015).

There is a paradox when it comes to the highly lucrative European market. The Czech Republic makes its way through a limited extent of products with higher values added and dominates in unprocessed and semi-finished goods. On the other hand, in relation to Non-EU countries, particularly countries outside Western Europe, the commodity structure is mainly directed towards exporting products with a higher degree of processing (Bašek and Kraus, 2009) and higher unit prices. One might consider the Czech Republic as a colony of "old EU member countries", as Czech exports have been performed for low price, but imports have been performed for much higher price and the level of Czech agri-food market dependency on „old EU members" is increasing. In fact the Czech Republic is not able to compete through added value performance. In the case of many items, the only comparative advantage of Czech agri-food performance is low price.

To clarify the statement mentioned above, it is necessary to explain that the Czech agrarian trade is to a great extent disadvantaged when compared to a number of its competitors. The Czech Republic is a so called "landlocked country", without sea or ocean access, which in a very significant way limits the export potential of Czech agrarian and food products in relation to non-European regions. As Czech access to non-EU markets is limited (because of transaction costs), the majority of Czech food exports have been performed within EU market which could be considered as one of the most competitive in the world. The competitive characteristics of the EU market does not provide enough opportunities for Czech producers to significantly change the structure of production. The low level of margin does not provide enough sources for investments to change the commodity structure profile. More and more Czech producers have been suffering because of intense competition and pressure from other EU countries.

\section{MATERIALS AND METHODS}

This article is focused on the issues of the transformation of the commodity structure of the Czech agrarian trade from 2001 until 2016. The monitored period includes conditions before the entrance to the EU and in more detail, 
the situation after the entrance of the Czech Republic into the EU. The structure of the article is divided into four parts. Firstly, the analysis of the restructualization of the commodity structure of the Czech agrarian trade is conducted compared to that of all trade partners (world). Secondly, the commodity structure is separately analyzed in comparison to EU countries vs. Non-EU countries (all non-member countries of EU28). Our analysis is realized and evidenced through the application 'product mapping' approach. Here, the analysis completed through the calculations of RCA, LFI and TBI indices. Its application then makes it possible to divide the commodity structure into four segments, according to their comparative advantages and value of balance.

The objective of this paper is to identify the principles of Czech agrarian trade competitiveness in relation to EU and non-EU countries (As the Czech agrarian trade profile differs in relation to EU and non-EU market, the above mentioned analysis is conducted separately for the EU market and separately for the non-EU market.). The results of the comparative advantages analyses are discussed in relation to Czech agrarian trade nominal value and volume performance. The purpose of the paper is to provide a clear overview of comparative advantages distribution. The second purpose is to identify the main source of increased trade performance at the level of individual trade items.

The commodity structure (we applied the $\mathrm{CN}$ system ${ }^{1}$ of dividing agrarian trade into 24 commodity groups) is analyzed primarily in relation to added value development and distribution. The mentioned commodity structure system is applied because of the results are easier to interpret and also because of data availability. Data sources for individual analyses are the following: UN COMTRADE, and the Czech statistical office. Collected data covers the following categories: export and import value and volume, and the unit value of realized exports and imports. The paper analyzes through the use of basic statistical indicators and the general development trends of export and import value and volume. The other analyzed categories are export/import coverage ratio and export and import unit value development. An important part of the analysis is related to the problem of comparative advantages distribution. The ambition of the paper is to specify the main driver of Czech agrarian trade value development. In this case, the paper specifies whether the main driving force of Czech agrarian trade value is unit value of traded products or volume performance. The analyses are performed in relation to the above specified group of countries representing trade partners of the Czech Republic. As it was mentioned before, we applied several different types of indices to measure the level of Czech agrarian trade comparative advantage. The basic indicator applied to discover the real state of Czech agrarian trade comparative advantages distribution is the standard RCA index, (proposed by Ballasa (1965; 1977) later modified by Volrath (1991).

$$
R C A_{i j}=\frac{X_{i j}-M_{i j}}{\sum_{i} X_{i j}+M_{i j}} / \frac{\sum_{j} X_{i j}-\sum_{j} M_{i j}}{\sum_{i} X_{i j}+\sum_{j} M_{i j}},
$$

where $X_{i j}$ and $M_{i j}$ represent country i's export and import of product j. $R C A_{i j}>1$ indicates that country $i$ has a comparative advantage in production of $j$; thus the greater the index, the stronger the advantage. $R C A_{i j}<1$ indicates that country $i$ has a comparative disadvantage in the production of $j$; thus the smaller the index, the greater the disadvantage. The advantage of the RCA index is its ability to identify comparative advantages/disadvantages existing at a general level, but it is not able to identify the partial comparative advantages existing only at the bilateral level. To identify those existing comparative advantages we decided to apply a different index. For this index we used the Lafay index (Lafay, 1992). Using this index, we consider the difference between each item's normalized trade balance and the overall normalized trade balance. Unlike the above indices, The Lafay index does not take into account world variables. Using the LFI index, we can focus on the bilateral trade relations between countries and regions. Moreover, this index is more reliable in regards to the over-time comparison of sectors within a country. The Lafay

1 CN01 Live animals, CN02 Meat and edible meat offal, CN03 Fish and crustaceans, molluscs and other aquatic invertebrates, CN04 Dairy produce birds' eggs natural honey edible products of animal origin, not elsewhere specified or included, CN05 Products of animal origin, not elsewhere specified or included, CN06 Live trees and other plants bulbs, roots and the like cut flowers and ornamental foliage, CN07 Edible vegetables and certain roots and tubers, CN07 Edible vegetables and certain roots and tubers, CN08 Edible fruit and nuts peel of citrus fruit or melons, CN09 Coffee, tea, mate and spices, CN10 Cereals, CN11 Products of the milling industry malt starches inulin wheat gluten, CN12 Oil seeds and oleaginous fruits miscellaneous grains, seeds and fruit industrial or medicinal plants and fodder, CN13 Lac gums, resins and other vegetable saps and extracts, CN14 Vegetable plaiting materials vegetable products not elsewhere specified or included, CN15 Animal or vegetable fats and oils and their cleavage products prepared edible fats animal or vegetable waxes, CN16 Preparations of meat, of fish or of crustaceans, molluscs or other aquatic invertebrates, CN17 Sugars and sugar confectionery, CN18 Cocoa and cocoa preparations, CN19 Preparations of cereals, flour, starch or milk pastry cooks' products, CN20 Preparations of vegetables, fruit, nuts or other parts of plants, CN21 Miscellaneous edible preparations, CN22 Beverages, spirits and vinegar, CN23 Residues and waste from the food industries prepared animal fodder, CN24 Tobacco and manufactured tobacco substitutes 
I: Product mapping scheme (proposed by Widodo, 2009 and later modified by Smutka et al., 2015)

\begin{tabular}{|c|c|c|c|}
\hline \multirow{2}{*}{ Lafay index } & LFI $>0$ & $\begin{array}{l}\text { Group B: } \\
\text { Comparative Advantage } \\
\text { Net-importer } \\
(\text { LFI }>0 \text { and } \mathrm{TBI}<0)\end{array}$ & $\begin{array}{l}\text { Group A: } \\
\text { Comparative Advantage } \\
\text { Net-exporter } \\
(\text { LFI }>0 \text { and } \text { TBI }>0)\end{array}$ \\
\hline & LFI $<0$ & $\begin{array}{l}\text { Group D: } \\
\text { Comparative disadvantage } \\
\text { Net-importer } \\
(\mathrm{LFI}<0 \text { and } \mathrm{TBI}<0)\end{array}$ & $\begin{array}{l}\text { Group C: } \\
\text { Comparative disadvantage } \\
\text { Net-exporter } \\
(\text { LFI }<0 \text { and TBI }>0 \text { ) }\end{array}$ \\
\hline \multirow{2}{*}{\multicolumn{2}{|c|}{$\begin{array}{l}\text { Czech Agrarian Foreign Trade Commodity } \\
\text { Structure }\end{array}$}} & $\mathrm{TBI}<0$ & $\mathrm{TBI}>0$ \\
\hline & & \multicolumn{2}{|c|}{ Trade Balance Index } \\
\hline
\end{tabular}

*If TBI $=$ LFI $=0$, it is neutral state. But it is possible to consider this state as rather positive

Source: own modification and processing (2017)

index helps us to understand the comparative advantages over time and to compare the strength of comparative advantages of individual products and product groups, for individual regions and countries. For a given country, $i$, and for any given product $j$, the Lafay index is defined as:

$L F I_{j}^{i}=100 \times\left(\frac{x_{j}^{i}-m_{j}^{i}}{x_{j}^{i}+m_{j}^{i}}-\frac{\sum_{j=1}^{N}\left(x_{j}^{i}-m_{j}^{i}\right)}{\sum_{j=1}^{N} x_{j}^{i}+m_{j}^{i}}\right) \frac{x_{j}^{i}+m_{j}^{i}}{\sum_{l=1}^{N} x_{j}^{i}+m_{j}^{i}}$,

where $x_{j}^{i}$ and $m_{j}^{i}$ are exports and imports of product $j$ of country $i$, towards and from the particular region or the rest of the world, respectively, and $N$ is the number of items. Positive values of the Lafay index indicate the existence of comparative advantages in a given item; the larger the value the higher the degree of specialization (Zaghini, 2003). The next part of the analysis presented in this paper was conducted using the analytical tool, called "Products Mapping”. This tool allows the user to assess leading exported products from two different points of view, i.e. domestic trade-balance and international competitiveness (Widodo, 2009). The Product Mapping approach is based on the application of two different indices: The LFI index and The TBI index. Trade Balance Index (TBI) is employed to analyze whether a country has a specialization in exporting (as net-exporter) or in importing (as netimporter) for a specific group of products. TBI is simply formulated as follows:

$T B I_{i j}=\frac{\left(x_{i j}-m_{i j}\right)}{\left(x_{i j}+m_{i j}\right)}$,

where $T B I_{i j}$ denotes the trade balance index of country $i$ for product $j ; x_{i j}$ and $m_{i j}$ represents exports and imports of a group of products $j$ by country $i$, respectively (Lafay, 1992). A country is referred to as "net-importer" in a specific group of products if the value of TBI is negative, and as "net-exporter" if the value of TBI is positive (Widodo, 2009).
Tab. I represents a matrix for the distribution of the entire set of exported products into 4 groups according to the two selected indicators (LFI and TBI). The LFI index is chosen for the "product mapping" approach because of its ability to take into consideration only those transactions which are really related to individual countries' trade performance (in this case the Czech Republic's trade performance). The TBI index is applied for its ability to divide the products according to their real trade performance into the above four specified quadrants. The chosen approach provides the ability to specify the comparative advantages on the base of real bilateral trade performance (in relation to the selected group of partners).

\section{Commodity Structure Changes in Agrarian Trade of the Czech Republic}

Czech agrarian trade has in the recent years undergone a dynamic transformation, not only in when it comes to its own value, but also volume and unit prices in both exports and imports. From 2001 to 2016, the turnover value of realized transactions increased from approximately 118 bil. CZK to approximately 426 bil. CZK. While the value of realized transactions increased very significantly, the trade balance, although fluctuating sharply over the years, had not changed considerably during the monitored period. During the selected period, the trade balance was about twenty bil. CZK. Even though the values of both exports and imports increased dramatically, the share of negative balance in relation to the turnover of the Czech agrarian trade had been significantly converging as a result of a higher growth rate of the agrarian exports value in comparison with the agrarian imports value. In the selected period the share of negative balance on turnover had been reduced from approx. $17 \%$ to approx. 5\%. A specific characteristic of Czech agrarian trade during monitored period was the significantly higher growth rate of agrarian trade volume in comparison with the agrarian trade value, particularly in the case of agrarian exports. In the selected period, the volume of agrarian exports increased from about 3.1 million tonnes 
II: Basic overview of Czech agrarian trade development in 2001-2016 (in ths. CZK and in tons)

\begin{tabular}{lrrrrrr}
\hline Commodity name & \multicolumn{1}{c}{2001} & \multicolumn{1}{c}{2003} & \multicolumn{1}{c}{2005} & \multicolumn{1}{c}{2007} & \multicolumn{1}{c}{2011} & \multicolumn{1}{c}{2016} \\
\hline Export: volume & 3086229 & 7380650 & 9962309 & 10983445 & 14265625 & 16100490 \\
Export: value & 49411501 & 48804648 & 78519645 & 96879927 & 120380667 & 201592372 \\
\hline Import: volume & 3110899 & 3678744 & 4579740 & 5049164 & 6122807 & 7535938 \\
Import: value & 69228289 & 74259292 & 103522390 & 129333033 & 156673575 & 224676654 \\
\hline Balance: volume & -24669 & 3701906 & 5382568 & 5934282 & 8142818 & 8564552 \\
Balance: value & -19816788 & -25454644 & -25002745 & -32453106 & -36292908 & -23084282 \\
\hline
\end{tabular}

Source: CZSO (2017)

to more than 16.1 million tonnes, while the value increased from CZK 49 billion to CZK 201.6 billion. In the case of agrarian imports, it was the opposite. Significantly higher dynamics showed import value growth from CZK 69 billion to CZK 224 billion, while the volume of realized imports increased from only 3.1 million tonnes to 7.54 million tonnes (details concerning development of the value and volume of agrarian trade of the Czech Republic can be found in Tab. II).

The result of the above-mentioned development is an interesting point concerning the relationship between the volume and value of the Czech agrarian trade. While the value of the Czech agrarian trade is in a long-term deficit (sum of exports and imports in the monitored period was approx. 1.8 tril. CZK and 2.2. tril. (ZK), when it comes to trade volume, the Czech agrarian trade can be seen as having a high surplus. During the years from 2001 to 2016, the Czech Republic exported around 191 mil. tonnes of agrarian and food products, while at the same time imported only 86 mil. tonnes. That is more than one hundred million tons in export surplus. Based on the individual analyses' results (see appendix), it is possible to see a significantly higher dynamic of import price development compared to export prices. While the unit price of imports grew by an average of $2 \%$ per year in the selected period, the unit price of exports declined by less than two percent. The resulting imbalance created a situation where, in 2001, the average kilogram price of exports and imports was CZK 16 and CZK 22.25, and in 2016 it was already CZK 12.5 and CZK 29.8. From the perspective of unit price development, the Czech export price decreased by about 25\% per kilogram, while the import price increased by about 30\%. This evidence suggests that the main driving force of Czech agrarian export is primarily the continuously growing volume of exported mass and the constantly falling unit price of exports. In the monitored period, the negative growth rate of unit prices was recorded primarily for the following commodity aggregates: live animals, meat and edible offal, milk, dairy products and eggs, animal products, cereals, vegetable knitting materials and non-alcoholic beverages.
These are in general the aggregates that represent the main pillars of Czech agrarian exports, within which approximately $73 \%$ of the volume of annual agrarian exports is realized. In 2016 it was approximately 11 million tonnes out of the total of more than 16 million tonnes of Czech agrarian exports. Even though the trend of this direction is undesirable, it may have a positive side. The agrarian trade volume in the case of these other aggregates, had in the selected period increased from 1.7 mil. tonnes to 4.3 mil tons per year. Nonetheless, the growth dynamics of export volume within these seventeen aggregates was significantly lower in comparison with the seven previous aggregates, where the yearly growth rate of volume of the first groups reached $15 \%$. Whereas in the case of the second group, it was only $6 \%$ per year. On the other hand, the higher dynamics of the value growth in the case of the second group of aggregates with $10 \%$, compared to the second group with $9 \%$, is a positive aspect.

A relatively disappointing discovery was the fact that it is the aggregates with lower degree of processing and continuously decreasing per kilogram prices, which show better results in the area of long-term balance of the Czech agrarian trade. While the first group of aggregates has showed a positive balance of approximately 36 bil. CZK in the years 2001 to 2016, the second group of aggregates has shown a significantly higher balance in a cumulative value exceeding 467 bil. CZK. From the above mentioned study, certain assumptions can be drawn for the purpose of the analysis of competitiveness, or more precisely the comparative advantages of the Czech agrarian trade, which are to a certain point based on the ability of the Czech Republic to be successful in exports of products with a lower degree of processing. Whereas, the export strategy is primarily built on the high volume of exported mass and low export prices. This fact is also supported by the analysis conducted through LFI, RCA and TBI indices.

Nevertheless, it is not possible to evaluate the Czech agrarian trade only based on its overall results in relation to all its trade partners simultaneously. The Czech agrarian trade, as it has already been demonstrated, has a very specific 
III: Product mapping - Commodity structure of Czech agrarian trade in relation to EU28

\begin{tabular}{|c|c|c|c|c|c|c|c|c|c|}
\hline B & $\begin{array}{c}\text { Share } \\
\text { in export }\end{array}$ & $\begin{array}{c}\text { Unit export } \\
\text { price } \\
\text { in CZK/kg }\end{array}$ & $\begin{array}{c}\text { Share } \\
\text { in import }\end{array}$ & $\begin{array}{c}\text { Unit import } \\
\text { price } \\
\text { in } \mathrm{CZK} / \mathrm{kg} \\
\end{array}$ & A & $\begin{array}{c}\text { Share } \\
\text { in export }\end{array}$ & $\begin{array}{l}\text { Unit price } \\
\text { in } \mathrm{CZK} / \mathrm{kg}\end{array}$ & $\begin{array}{l}\text { Share } \\
\text { in import }\end{array}$ & $\begin{array}{l}\text { Unit import } \\
\text { price in } \\
\mathrm{CZK} / \mathrm{kg}\end{array}$ \\
\hline & & & & & CN10 & $9.01 \%$ & 4.71 & $1.57 \%$ & 8.50 \\
\hline & & & & & $\mathrm{CN} 24$ & $9.10 \%$ & 446.69 & $4.42 \%$ & 238.71 \\
\hline & & & & & CN01 & $4.19 \%$ & 46.39 & $1.04 \%$ & 62.16 \\
\hline & & & & & CN12 & $4.71 \%$ & 12.67 & $2.69 \%$ & 8.98 \\
\hline & & & & & CN15 & $6.80 \%$ & 20.06 & $5.57 \%$ & 20.57 \\
\hline & & & & & CN04 & $8.78 \%$ & 15.53 & $7.89 \%$ & 43.55 \\
\hline & & & & & CN22 & $7.59 \%$ & 1.40 & $6.81 \%$ & 20.61 \\
\hline & & & & & CN11 & $1.67 \%$ & 9.59 & $0.94 \%$ & 10.99 \\
\hline & & & & & CN17 & $3.95 \%$ & 22.77 & $3.31 \%$ & 14.50 \\
\hline & & & & & CNO3 & $1.67 \%$ & 118.74 & $1.05 \%$ & 89.25 \\
\hline & & & & & CN16 & $2.95 \%$ & 75.78 & $2.41 \%$ & 89.55 \\
\hline & & & & & CN09 & $6.04 \%$ & 184.05 & $5.74 \%$ & 161.82 \\
\hline & & & & & CN13 & $0.42 \%$ & 297.37 & $0.21 \%$ & 228.57 \\
\hline & & & & & CN14 & $0.05 \%$ & 6.56 & $0.04 \%$ & 0.49 \\
\hline & & & & & Total & $66.94 \%$ & 7.32 & $43.69 \%$ & 24.76 \\
\hline D & $\begin{array}{l}\text { Share } \\
\text { in export }\end{array}$ & $\begin{array}{l}\text { Unit export } \\
\text { price } \\
\text { in CZK/kg }\end{array}$ & $\begin{array}{c}\text { Share } \\
\text { in import }\end{array}$ & $\begin{array}{c}\text { Unit import } \\
\text { price } \\
\text { in } \mathrm{CZK} / \mathrm{kg}\end{array}$ & C & $\begin{array}{l}\text { Share } \\
\text { in export }\end{array}$ & $\begin{array}{l}\text { Unit export } \\
\text { price } \\
\text { in } \mathrm{CZK} / \mathrm{kg}\end{array}$ & $\begin{array}{c}\text { Share } \\
\text { in import }\end{array}$ & $\begin{array}{l}\text { Unit import } \\
\text { price } \\
\text { in } \mathrm{CZK} / \mathrm{kg}\end{array}$ \\
\hline CN05 & $0.66 \%$ & 16.24 & $0.82 \%$ & 12.44 & & & & & \\
\hline CN21 & $6.54 \%$ & 74.13 & $6.80 \%$ & 66.20 & & & & & \\
\hline CN19 & $6.18 \%$ & 54.58 & $6.93 \%$ & 50.91 & & & & & \\
\hline CN23 & $5.63 \%$ & 9.67 & $6.44 \%$ & 12.10 & & & & & \\
\hline CN18 & $4.44 \%$ & 129.19 & $5.85 \%$ & 112.66 & & & & & \\
\hline CN06 & $0.40 \%$ & 59.06 & $2.18 \%$ & 50.93 & & & & & \\
\hline CN20 & $1.69 \%$ & 35.52 & $3.54 \%$ & 28.63 & & & & & \\
\hline CN08 & $2.58 \%$ & 19.57 & $5.13 \%$ & 20.50 & & & & & \\
\hline CN07 & $1.61 \%$ & 16.12 & $6.16 \%$ & 14.51 & & & & & \\
\hline CNO2 & $3.34 \%$ & 64.03 & $12.45 \%$ & 52.15 & & & & & \\
\hline Total & $33.06 \%$ & 27.64 & $56.31 \%$ & 28.59 & & & & & \\
\hline
\end{tabular}

Source: own processing, 2017

commodity, but also territorial structure, which is focused on specific groups of countries, against which, although not competitive as whole, the Czech Republic is able to reach comparative advantages on a bilateral basis and a specific commodity mix.

\section{EU28 vs. Non-EU Countries}

When it comes to the Czech agrarian trade, it is the EU28 countries that play the key role and which participate in the turnover of the Czech agrarian trade the most. On the other hand, the non-member countries only make up a territorial complement of Czech agro trade. Although a non- negligible amount of Czech exports and especially imports is actualized with Non-EU countries, this fact is hidden behind a system of re-exports and processing operations within, which the EU28 countries as a trade partner of the Czech Republic. The cause of this phenomenon is the geographical location of the Czech Republic, which is "trapped" in the middle of Europe as a so called "land locked country"; moreover without any maritime access, which plays a key role in the development of trade with non-European countries. If we were to focus on the comparison of characteristics of the Czech agrarian trade realized in relation to countries of 
IV: Product mapping - Commodity structure of the Czech agrarian trade in relation to "Non-EU countries"

\begin{tabular}{|c|c|c|c|c|c|c|c|c|c|}
\hline B & $\begin{array}{c}\text { Share } \\
\text { in export }\end{array}$ & $\begin{array}{c}\text { Unit export } \\
\text { price } \\
\text { in CZK/kg }\end{array}$ & $\begin{array}{c}\text { Share } \\
\text { in import }\end{array}$ & $\begin{array}{c}\text { Unit import } \\
\text { price } \\
\text { in CZK/kg } \\
\end{array}$ & A & $\begin{array}{l}\text { Share } \\
\text { in export }\end{array}$ & $\begin{array}{l}\text { Unit price } \\
\text { in } \mathrm{CZK} / \mathrm{kg}\end{array}$ & $\begin{array}{l}\text { Share } \\
\text { in import }\end{array}$ & $\begin{array}{c}\text { Unit import } \\
\text { price } \\
\text { in } \mathrm{CZK} / \mathrm{kg}\end{array}$ \\
\hline & & & & & CNO4 & $17.27 \%$ & 60.00 & $0.74 \%$ & 77.73 \\
\hline & & & & & CN17 & $9.41 \%$ & 13.18 & $1.27 \%$ & 38.95 \\
\hline & & & & & CN01 & $7.70 \%$ & 107.18 & $0.11 \%$ & 1146.79 \\
\hline & & & & & CN24 & $9.15 \%$ & 721.39 & $2.52 \%$ & 99.19 \\
\hline & & & & & CN12 & $7.15 \%$ & 88.45 & $2.40 \%$ & 46.47 \\
\hline & & & & & CN19 & $4.48 \%$ & 73.16 & $1.16 \%$ & 51.00 \\
\hline & & & & & CN11 & $3.81 \%$ & 11.46 & $0.52 \%$ & 33.33 \\
\hline & & & & & CN13 & $3.98 \%$ & 306.18 & $1.80 \%$ & 273.14 \\
\hline & & & & & CN18 & $1.76 \%$ & 161.36 & $0.70 \%$ & 144.63 \\
\hline & & & & & Total & $64.72 \%$ & 40.83 & $11.21 \%$ & 66.40 \\
\hline $\mathrm{D}$ & $\begin{array}{l}\text { Share } \\
\text { in export }\end{array}$ & $\begin{array}{c}\text { Unit export } \\
\text { price } \\
\text { in } \mathrm{CZK} / \mathrm{kg}\end{array}$ & $\begin{array}{l}\text { Share } \\
\text { in import }\end{array}$ & $\begin{array}{c}\text { Unit import } \\
\text { price } \\
\text { in } \mathrm{CZK} / \mathrm{kg}\end{array}$ & A & $\begin{array}{l}\text { Share } \\
\text { in export }\end{array}$ & $\begin{array}{l}\text { Unit price } \\
\text { in CZK/kg }\end{array}$ & $\begin{array}{c}\text { Share } \\
\text { in import }\end{array}$ & $\begin{array}{c}\text { Unit import } \\
\text { price } \\
\text { in } \mathrm{CZK} / \mathrm{kg}\end{array}$ \\
\hline CN14 & $0.00 \%$ & 95.52 & $0.10 \%$ & 10.78 & CN23 & $10.41 \%$ & 43.99 & $5.52 \%$ & 26.29 \\
\hline CN05 & $1.39 \%$ & 104.51 & $1.67 \%$ & 194.33 & CN22 & $12.06 \%$ & 20.86 & $8.12 \%$ & 36.83 \\
\hline CN06 & $0.06 \%$ & 99.54 & $1.04 \%$ & 164.36 & Total & $22.47 \%$ & 27.60 & $13.64 \%$ & 31.68 \\
\hline CN10 & $0.97 \%$ & 11.96 & $2.18 \%$ & 16.67 & & & & & \\
\hline CN15 & $0.11 \%$ & 23.86 & $1.49 \%$ & 25.12 & & & & & \\
\hline CN16 & $0.85 \%$ & 73.30 & $3.24 \%$ & 92.97 & & & & & \\
\hline CN21 & $6.28 \%$ & 128.59 & $8.87 \%$ & 112.79 & & & & & \\
\hline CN20 & $1.03 \%$ & 60.87 & $4.68 \%$ & 47.58 & & & & & \\
\hline CN07 & $0.27 \%$ & 24.11 & $4.66 \%$ & 32.30 & & & & & \\
\hline CNO2 & $0.84 \%$ & 85.60 & $7.78 \%$ & 90.04 & & & & & \\
\hline CN09 & $0.77 \%$ & 168.56 & $8.52 \%$ & 106.29 & & & & & \\
\hline CNO3 & $0.19 \%$ & 168.06 & $8.60 \%$ & 101.73 & & & & & \\
\hline CN08 & $0.06 \%$ & 53.33 & $22.30 \%$ & 30.08 & & & & & \\
\hline Total & $12.82 \%$ & 62.66 & $75.14 \%$ & 48.10 & & & & & \\
\hline
\end{tabular}

Source: own processing, 2017

the EU28 and with Non-EU countries, it is possible to identify the following differences and facts, which are typical in relation with the analyzed groups of countries.

The value of the Czech agrarian exports and imports in relation to the EU28 has increased in the years 2001 to 2016 from 42 bil. CZK to almost 186 bil. CZK and from 51 bil CZK to approx. 189 bil. CZK. The negative balance of mutual agrotrade had then significantly approached the values of "balanced" trade, where the negative balance of mutual trade during the period had decreased from approx. $11 \%$ to $0.9 \%$. Alternatively, the value of agrarian exports and imports in relation to Non-EU countries in the monitored period had increased from 8.3 bil CZK to 26.9 bil CZK and from approx. 18 bil CZK to 32.6 bil CZK. The growth dynamics in relation to Non-EU countries did not exceed the growth dynamics of trade in relation to EU28 countries and therefore the share of these countries on the Czech agrarian trade had been decreasing. A characteristic feature of Czech trade with Non-EU countries is the relatively high negative balance (in the monitored period the negative balanced increased from approx. 9.7 bil CZK to approx. 16 bil CZK) in relation to turnover from the realized trade. Nonetheless, the share of the negative balance on the realized trade turnover has been gradually decreasing from approx. 37\% to $32 \%$.

If we apply the approach described in the methodology of "product mapping", it can be stated that in the case of the EU28 countries, as the export partner of the Czech Republic, most of the value of exports is built on transactions with comparative 
advantages. In 2001, comparative advantages had the following aggregations: oil seeds, beverages and spirits, tobacco products, milk and milk products, milling industry products, live animals, sugar and confectionery, fish and crustaceans. In 2016, the comparative advantages has been found out in the case of the following aggregations: cereals, tobacco products, live animals, oil seeds, animal and vegetable fats, milk and milk products, beverages and spirits, milling industry products, sugar and confectionery, fish and crustaceans, meat preparations, coffee, tea, mate and spices, lac gums and resins, and vegetable planting materials. From the point of view of the competitiveness of Czech agrarian trade, it is suggested that there has been an improvement in the competitive position of a number of aggregates in relation to EU28 countries over the monitored period and in addition to the strengthening of the role of Group A (see methodology) in Czech agrarian trade. Within the aggregate segment showing positive LFI and TBI index, it can be observed that the value of exports and imports increased from CZK 23 billion to CZK 124 billion and from CZK 12.6 billion to CZK 82 billion. The weakness of Czech trade within this segment of goods, is primarily its export structure that is built on high volume items with low added value. While in 2001, Czech exports and imports within this aggregate group were realized at CZK 12.8/kg and CZK 18.24/kg, by 2016 the difference in the per kilogram prices of exports and imports has worsened to the detriment of Czech agrarian trade. The price of one kilogram of export was at CZK 7.32, which was significantly lower compared to the import price of $24.76 \mathrm{CZK} / \mathrm{kg}$. In this respect, Czech agrarian exporting is based on the export of massive goods at a low price, and this trend persists despite the efforts of a number of agrarian market players. The following data regarding the development of the mass of the realized exports and imports within the above specified group of goods can be mentioned only for reflection. While in 2001, in the monitored group of products with comparative advantages, export and imports volumes amounted to approximately 1.79 million tonnes and 0.693 billion tonnes, and in 2016 it was approximately 17 million tonnes and 3.3 million tonnes. It can be suggested from the above information that the mass of exports has almost doubled, and therefore the comparative advantages of Czech agro-trade with the EU-28 countries are built primarily on mass at a consistently decreasing price per kilogram. This is generally a long-term weakness of the entire Czech agrarian trade market, which as a whole, in 2001, recorded 28 kilograms of exports for 20.5 CZK and in 2016 only for 9.7 CZK. On the other hand, kilogram import prices in the long run grew from CZK 14.5 in 2001 to about CZK 27 in 2016. In the case of aggregates grouped in quadrant D (i.e. items, which do not have comparative advantages or characteristic negative values of LFI and TBI indices) the outlook is much better, at least in the case of per kilogram prices and number of traded products. The value of exports within these aggregates had in the monitored period increased from 16 bil. CZK to more than 62 bil. CZK. The growth dynamics of export was significantly higher in comparison with growth dynamics of import, where the value increased in the monitored years from 36 bil. CZK to more than 106 bil. CZK. This contradictory occurrence is factual, in that the share of items in the framework of the "noncompetitive" part of the Czech agro trade during the monitored period decreased even more dynamically than in the case of the share of exports realized within this category. The high dynamics of the growth of the value of agrarian export in this category of aggregates lends credibility to the significant territorial difference of Czech agrarian trade within the EU28, where it is evident that even though the Czech Republic does not have an comparative advantage against EU28 as a whole, it is possible to state that at least against a certain number of EU28 members, the Czech republic holds a comparative advantage (this is by the way a very interesting topic for more thorough analysis which focuses in detail on the territorial structure of the Czech AZO in relation to other individual member countries from the EU28). The previously mentioned group of products is also very interesting from perspective of the development of per kilogram prices of closed trade transactions. During the compared years the price of exports increased from about $16 \mathrm{CZK} / \mathrm{Kg}$ to $27.64 \mathrm{CZK} / \mathrm{kg}$. On the other hand the price of imports increased from $14.5 \mathrm{CZK} / \mathrm{kg}$ to $28.6 \mathrm{CZK} / \mathrm{kg}$. The prices then stayed in relative parity. The volume of growth in volume of export is also relatively balanced. In the case of exports, the trade volume increased from $1 \mathrm{mil}$. tonnes to approx. 2.2 mil tonnes, and in case of imports the volume increased from 1.75 mil tonnes to approx. 3.7 mil. tonnes. It is a paradox that with this segment, which does not have a comparative advantage, the Czech agrarian trade shows significantly "weaker" results based on the level of value added. That is in the case of the commodity segment, which does have comparative advantages. In the case of the EU28, the Czech agrarian trade recorded significant changes during the monitored years. In the case of Non-EU countries - i.e. non-EU countries - the restructuring represents even more significant shifts leading to even more weakening of the share of these countries in the Czech AZO. Volume, value and the price of closed contracts experienced significant changes. While in 2001 the value of exports and imports was about CZK 8 billion and about CZK 18 billion. With both export and import per kilogram prices, it was $32.3 \mathrm{CZK}$ and 29.2 CZK. In 2016, the value of exports and imports 
amounted to approximately CZK 17 billion and CZK 32 billion. The average per kilogram export and import prices then fluctuated around approx. 38 CZK to 46.24 CZK. The volume of closed contracts increased from 247,678 to 447,368 tonnes in the case of exports; and in the case of imports, the increase in transaction volume was only slight, from 616,438 tonnes to 692,041 tonnes. It is therefore apparent from the above values that the values characterizing trade with Non-EU countries, are significantly lower and different in comparison with the EU28 countries. What is more interesting is the commodity structure. Especially, if we divide the commodity structure into parts with comparative advantages (a group of aggregations A) and without comparative advantages (a group of aggregations D). Within Group A (ie, aggregations with comparative advantages according to the positive values of LFI and TBI), in 2001 and 2016 the value of agricultural exports and imports increased from CZK 6.4 billion to CZK 11 billion and from CZK 0.831 billion CZK to 3.65 billion. On the opposite side, in the case of aggregations without a comparative advantage (Group D), export and import values grew from CZK 1 billion to CZK 2.2 billion and from CZK 16 billion to CZK 24.45 billion. It follows from the above mentioned point, that group A aggregates have experienced more turbulent developments over the monitored years compared to that of Group D aggregates. This can be explained in particular by the fact that within Group A transactions, in terms of the territorial structure trade, non-EU OECD members and CIS countries were dominant. Unfortunately trade activities in relation to Russia have suffered because of EU-Russian political tension and economic sanctions (Kontsevaya et al., 2016; Kharcheva et al., 2016), while for Group D it was primarily long-term non-competitive products being imported from developing countries. In the analyzed time period, the long term comparative advantages were shown by the following aggregations: milk and milk products, sugar and confectionery, beverages and spirits, milling industry products, live animals, lac gums and resins, preparations of cereals, tobacco products, oil seeds, and cocoa and cocoa preparations.

From the results from the analysis it can be stated that the commodity structure of items, within which the Czech Republic has a comparative advantage in relation to Non-EU countries, has significantly expanded during the monitored years. Furthermore, it is clear from the outcomes that the growth in export value is more than that of EU countries based on higher added value products and higher kilogram prices. Also, the imbalance between export and import prices within this group of countries is not as significant as that of the EU28, where the main comparative advantage of the Czech Republic is low prices. Within the group of products included in group A (positive value of LFI and TBI), export and import prices were on average at CZK 28.8/ kg and CZK 41/kg and in 2016 it was CZK 40.9/ $\mathrm{kg}$ and 66,40 CZK/ kg. It is a paradox that comparative advantages are again realized primarily through low prices and high volumes of goods, where the physical volume of exports increased from 221703 tonnes to 286786 , i.e. the volume is significantly higher compared to the volume of imports, which increased from 20270 tonnes to 54952 tonnes. In the case of segment D (no comparative advantages), the differences between the export and import prices are not that significant within the monitored years, where the prices increased from $41.84 \mathrm{CZK} / \mathrm{kg}$ to $62.66 \mathrm{CZK} / \mathrm{kg}$ and from $29.26 \mathrm{CZK} / \mathrm{kg}$ to 48 CZK 10/kg. Export prices are significantly higher than import prices. Thus, the growth of value is not "driven" primarily by the increase in the volume of traded goods. During the monitored years, the volume of exports increased from 24779 tonnes to 34423 tonnes. On the contrary, imports are permanently built on a large volume of imported and relatively limited processed material, which, however, had grown very limitedly over time from 508,606 tonnes to 546,006 tonnes.

\section{The Role of Unit Value and Volume in Changing Czech Agrarian Exports Performance}

As previously mentioned, the value of Czech agrarian exports are constantly increasing. The competitiveness of individual items is significant both in relation to the EU market and also in relation to the non-EU market. Based on the analyses, it is possible to divide individual trade items into two groups. Those which trade performance is induced by increasing volume and those which trade performance is induced by especially increasing unit price. A critical situation arises specifically in relation to EU28 countries. The increasing export value performance is induced especially by increasing volume performance. In addition, the influence of unit value development is negative (for details see Tab. V). In relation to non-EU countries the situation is much better. But the influence of increasing volume performance is still much higher in comparison to unit value growth.

In relation to EU28 countries, the export value performance is pushed by driven by increasing unit values in only the following items: oil seeds, live trees and plants, preparations of vegetables, cocoa and cocoa preparations, residues and waste of food industry, edible fruits, fish, coffee, tea and spices, miscellaneous edible preparations, tobacco and tobacco products, vegetables, lac gums and resins, sugar and confectionery, preparations of cereals, preparations of meat, animal and vegetable fats and oils. But only in the case of the first three, the influence of unit value growth is higher than 
V: The role of unit value and simple volume performance in the process of Czech export value performance development in relation to the EU28 and non-EU countries (2001/2016)

\begin{tabular}{|c|c|c|c|c|c|}
\hline \multicolumn{3}{|c|}{ EU28 } & \multicolumn{3}{|c|}{ Non-EU countries } \\
\hline $\mathrm{CN}$ & $\begin{array}{l}\text { The share of volume } \\
\text { performance } \\
\text { in export value growth }\end{array}$ & $\begin{array}{l}\text { The share of unit } \\
\text { value performance } \\
\text { in export value growth }\end{array}$ & $\mathrm{CN}$ & $\begin{array}{l}\text { The share of volume } \\
\text { performance } \\
\text { in export value growth }\end{array}$ & $\begin{array}{l}\text { The share of unit } \\
\text { value performance } \\
\text { in export value growth }\end{array}$ \\
\hline CN12 & $-6.74 \%$ & $106.74 \%$ & CN08 & N/A (volume drop) & N/A (value growth) \\
\hline CN06 & $10.69 \%$ & $89.31 \%$ & CN16 & $-128.39 \%$ & $228.39 \%$ \\
\hline CN20 & $34.60 \%$ & $65.40 \%$ & CN06 & $-31.16 \%$ & $131.16 \%$ \\
\hline CN18 & $52.21 \%$ & $47.79 \%$ & CN21 & $15.35 \%$ & $84.65 \%$ \\
\hline CN23 & $62.61 \%$ & $37.39 \%$ & $\mathrm{CN} 24$ & $25.01 \%$ & 74.99\% \\
\hline CN08 & $64.61 \%$ & $35.39 \%$ & CN20 & $36.49 \%$ & $63.51 \%$ \\
\hline $\mathrm{CNO} 3$ & $66.87 \%$ & $33.13 \%$ & CN19 & $39.41 \%$ & $60.59 \%$ \\
\hline CNO9 & $67.18 \%$ & $32.82 \%$ & CN18 & $44.95 \%$ & $55.05 \%$ \\
\hline CN21 & 69.83\% & $30.17 \%$ & CN09 & $45.20 \%$ & $54.80 \%$ \\
\hline CN24 & $75.50 \%$ & $24.50 \%$ & CN07 & $53.05 \%$ & $46.95 \%$ \\
\hline CN07 & $78.22 \%$ & $21.78 \%$ & CN01 & $55.49 \%$ & $44.51 \%$ \\
\hline CN13 & $79.01 \%$ & $20.99 \%$ & CNO4 & $58.38 \%$ & $41.62 \%$ \\
\hline CN16 & $82.07 \%$ & $17.93 \%$ & CN17 & $69.82 \%$ & $30.18 \%$ \\
\hline CN17 & $84.40 \%$ & $15.60 \%$ & CN05 & $72.13 \%$ & $27.87 \%$ \\
\hline CN19 & $86.70 \%$ & $13.30 \%$ & $\mathrm{CN} 23$ & $74.60 \%$ & $25.40 \%$ \\
\hline CN15 & $90.16 \%$ & $9.84 \%$ & CN13 & $90.30 \%$ & $9.70 \%$ \\
\hline CN11 & $103.46 \%$ & $-3.46 \%$ & CN11 & $91.57 \%$ & $8.43 \%$ \\
\hline CN10 & $105.02 \%$ & $-5.02 \%$ & $\mathrm{CN} 22$ & $92.07 \%$ & $7.93 \%$ \\
\hline CNO2 & $115.90 \%$ & $-15.90 \%$ & CN10 & $100.09 \%$ & $-0.09 \%$ \\
\hline CNO5 & $118.02 \%$ & $-18.02 \%$ & $\mathrm{CNO3}$ & $137.42 \%$ & $-37.42 \%$ \\
\hline CN01 & $131.91 \%$ & $-31.91 \%$ & CN14 & $142.51 \%$ & $-42.51 \%$ \\
\hline CN14 & $157.41 \%$ & $-57.41 \%$ & CN12 & $154.26 \%$ & $-54.26 \%$ \\
\hline CNO4 & $171.98 \%$ & $-71.98 \%$ & CN15 & $190.37 \%$ & $-90.37 \%$ \\
\hline CN22 & $192.64 \%$ & $-92.64 \%$ & CNO2 & $190.95 \%$ & $-90.95 \%$ \\
\hline Total & $113.78 \%$ & $-13.78 \%$ & Total & $87.94 \%$ & $12.06 \%$ \\
\hline
\end{tabular}

Source: own processing, 2018

the influence of volume performance growth. In the case of the other items (not mentioned before), the influence of unit value development is negative.

In relation to the non-EU countries, items having a positive unit value influence on export value performance are the following: preparations of meat, preparations of vegetables, live trees and plants, miscellaneous edible preparations, tobacco products, vegetables, fruits, preparations of cereals, cocoa preparations, coffee, tea and spices, live animals, dairy products, sugar and sweeteners, animal fodder, lac gums and resins, products of milling industry, beverages and spirits. The number of aggregations having supremacy of unit value growth over volume growth is much higher (in total - nine aggregations) in comparison to the EU28. In general, Czech agrarian trade's added value performance in relation to non-EU countries in comparison to EU28, is much better. The crucial disadvantage for Czech agrarian exports in regard to expanding outside of the EU28 is their lack of sea or ocean access. 


\section{CONCLUSION}

The Czech agrarian trade has undergone some very significant changes to its characteristics in the past years. However, the process of transformation of its territorial and commodity structure has still not finished. The primary weakness of the Czech agrarian trade is its extreme focus on a limited number of trade partners. This is caused by a number reasons. First, the Czech Republic is a member of the EU28 and its agrarian trade is therefore realized under the conditions of the Common trade policy of the EU countries and is under the condition of the Single market. In addition, the Czech Republic is a typical so called 'land locked country' or without the access to any big harbors. Another reason is that the Czech agrarian trade suffers from its focus on the export of a relatively limited amount of high-volume items, which can only be exported abroad due to its lower per unit price, limited values added and also high transaction costs connected with its possible export in long distances. In the monitored period, Czech agrarian exports recorded a significant increase in its value and volume in both export and import, where the dynamics of growth in value and volume of export exceeded the dynamics in growth of import. Nonetheless, the Czech agrarian trade still suffers a long term deficit when it comes to the realized value. This, however, does not apply in the case of an export and import comparison when the Czech agrarian trade is in a long-term surplus. The weakness, but also at the same time, a comparative advantage of the Czech agrarian export is its significantly low per kilogram prices, which allow the Czech republic to get through with its exports on many and especially then European countries markets. This situation, although positive on one hand, cannot be perceived as very complimentary, due to the inability of the Czech Republic to focus on the export of products with higher degrees of processing and therefore higher value added. This could be considered as a very serious problem, if we take into account that a developed industrial country usually focuses mainly on the export of least processed or even unprocessed products, which make up the backbone of its exports. If we wanted to understand the characteristics of the Czech agrarian trade and its comparative advantages in more detail, it is necessary separately to do the analysis of relation to EU28 and "Non-EU countries". Taking this into account, it is then possible to state that the commodity structure of the Czech agrarian trade is different in relation to each group of countries individually. Furthermore, it is necessary to states that even comparative advantages are distributed differently among each of the analyzed segments. Last but not least, it is also necessary to state, that in relation to each analyzed groups of countries, the source of the comparative advantage is different. Specifically EU28, the comparative advantages mainly come from low price exports and high volume of realized trade (for details see Tab. V above). In the case of the "Non-EU countries", the comparative advantages come from products with higher values added and therefore with higher per kilogram prices (for details again see Tab. V). In general, it is possible to state that from a price level perspective and factoring in the degree of processing of the exported agrarian and food production, the Czech Republic achieves better results in relations to countries outside the EU28. Whereas in relation to the EU28 countries, the Czech agrarian trade can still be considered as untapped. While from the vantage point of coverage of value of imports by value of exports, the Czech agrarian trade is constantly improving and striving to reach a state of balance. Whereas this state is being ensured mainly by the export of items with lower degrees of processing (living animals, meat and meat products, dairy and dairy products, products of animal origin, cereals, beverages and spirits), in which the Czech Republic maintains a trade surplus, in the case of the other aggregates (mainly including products with higher degrees of processing), the Czech Republic has a long-term trade deficit. In relation to the EU28, those items are oil seeds, live trees and plants, preparations of fruits and vegetables, cocoa preparations, and edible fruits. In relation to the non-EU countries there are even more items which trade performance is induced especially in relation to the growth of unit prices and added value e.g. preparations of meat, miscellaneous edible preparations, plants and trees, edible fruits, tobacco and tobacco products, preparations of vegetables and fruits, preparations of cereals, cocoa preparations, coffee, tea and spices, edible vegetables, live animals and dairy and dairy products. With the above mentioned points, it has become clear that there is a strong need for further transformation of the Czech agrarian trade. With additional changes to the Czech agrarian trade market, the Czech Republic will closely mimic the standards of other developed European countries.

\section{Acknowledgements}

This paper has been made possible by the generous financial support of IGA, FEM, CULS Prague. [grant No. 20171024] - The analysis of Czech agrarian trade commodity structure.

This paper was supported by the Internal grant agency (IGA) of the Faculty of Economics and Management, Czech University of Life Sciences Prague, grant No. 2019B0011 "Economic analysis of water balance of the current agricultural commodities production mix in the Czech Republic" (Ekonomická analýza vodní bilance stávajícího produkčního mixu zemědělských komodit v ČR). 


\section{REFERENCES}

BALASSA, B. 1965. Trade liberalization and "revealed" comparative advantage. The Manchester School of Economics and Social Studies, 33(2): 99-123.

BALASSA, B. 1977. Revealed' Comparative Advantage Revisited. The Manchester School of Economics and Social Studies, 45(4): 327-44.

BAŠEK, V. and KRAUS, J. 2009. Czech foreign agricultural trade after joining the European Union. Agricultural Economics, 55(12): 583-595.

BOJNEC, S. and FERTO, I. 2018. Drivers of the duration of comparative advantage in the european Union's agri-food exports. Agricultural Economics, 64(2): 51-60.

BOJNEC, Š. and FERTŐ, I. 2017. Quality Upgrades of EU Agri-Food Exports. Journal of Agricultural Economics, 68(1): 269-279.

BURIANOVA, J. 2011. Agrarian foreign trade of the Czech Republic in the period of 2004-2008, competitiveness of commodities. Acta Universitatis Agriculturae et Silviculturae Mendelianae Brunensis, 59(4): 37-42.

BURIANOVA, J. 2011. Effect of the 2008-2009 economic crisis on the results of agricultural foreign trade of the Czech Republic. Agricultural Economics, 57(5): 226-231.

BURIANOVA, J. 2012. The competitiveness of agricultural foreign trade commodities of the CR assessed by way of the Lafay Index. Agris On-Line Papers in Economics ind Informatics, 4(4): 27-36.

BURIANOVA, J. and BELOVA, A. 2012. The competitiveness of agricultural foreign trade commodities of the CR assessed by way of the Lafay Index. Agris On-Line Papers in Economics and Informatics, 4(4): 27-36.

FERTŐ, I. 2008. The evolution of agri-food trade patterns in Central European countries. PostCommunist Economies, 20(1): 1-10.

FERTŐ, I. and HUBBARD L. J. 2003: Revealed Comparative Advantage and Competitiveness in Hungarian Agri-Food Sectors. The World Economy, 26(2): 247-259.

FULLER, F., BEGHIN, J. C., FABIOSA, J., MOHANTY, S., FANG, C. and KAUS, P. 2002. Accession of the Czech Republic, Hungary and Poland to the European union: Impacts on agricultural markets. World Economy, 25(3): 407-428.

JÁMBOR, A. 2014. Determinants of intra-industry agri-food trade in the Visegrad countries. Acta Alimentaria, 43(2): 246-253.

JAMBOR, A. 2014. Country-specific determinants of horizontal and vertical intra-industry agri-food trade: The case of the EU new member states. Journal of Agricultural Economics, 65(3): 663-682.

JAMBOR, A. and CARLOS LEITÃO, N. 2016. Industry-specific determinants of vertical intra-industry trade: the case of EU new member states' agri-food sector. Post-Communist Economies, 28(1): 34-48.

KANCS, D. and CIAIAN, P. 2010. Factor content of bilateral trade: The role of firm heterogeneity and transaction costs. Agricultural Economics, 41(3-4): 305-317.

KENNEDY, P. L. and SONNIER, G. P. 1997. Economic integration and international agricultural trade: The case of central and eastern Europe. Journal of International Food and Agribusiness Marketing, 9(3): 57-72.

KHARCHEVA, I., KONTSEVAYA, S. and MAITAH, M. 2016. Analysis of manpower resources utilization in agricultural organizations of the Russian federation. In: Economic Science for Rural Development. Proceedings of the International Scientific Conference, No. 42, pp. 244-249.

KONTSEVAYA, S., ALBOROV, R., KONTSEVAYA, S. et al. 2016. Estimation of current status of internal economic control in Russian agriculture. In: Economic Science for Rural Development. Proceedings of the International Scientific Conference, No. 43, pp. 290-295.

LAFAY, G. 1992. The measurement of revealed comparative advantages. In: DAGENAIS, M. G. and MUET, P. A. (Eds.). International Trade Modeling. London: Chapman \& Hill, pp. 209-234.

LUKAS, Z. 1998. Agricultural reforms in the CEFTA and EU eastern enlargement. Most, 8(2): 143-166.

MEZERA, J. and POHLOVA, K. 2014. Analysis of development of Czech foreign trade in foods and beverages. Agris On-Line Papers in Economics and Informatics, 6(4): 121-131.

NAGYOVÁ, L'., HORÁKOVÁ, M., MOROZ, S., HORSKÁ, E. and POLÁKOVÁ, Z. 2018. The analysis of export trade between Ukraine and Visegrad Countries. E+M: Ekonomie a management, 21(2): 115-132.

NOWAK, A. and KAMINSKA, A. 2016. Agricultural competitiveness: The case of the European Union countries. Agricultural Economics, 62(11): 507-516.

PRESOVÁ, R., TVRDOŇ, O. and ŽIVĚLOVÁ, A. 2008. Importance of intrastat in EU intra-Communtty trade. Acta Universitatis Agriculturae et Silviculturae Mendelianae Brunensis, 56(3): 175-186.

SMUTKA, L., STEININGER, M., MAITAH, M. et al. 2015. The Czech agrarian foreign trade - ten years after the EU accession. In: 24 $4^{\text {th }}$ International Scientific Conference on Agrarian Perspectives - Global Agribusiness and the Rural Economy. Prague, September 16-18, 2015, pp. 385-392. 
SVATOS, M. 2008. Selected trends forming European agriculture. Agricultural Economics/Zemědělská ekonomika, 54(3): 93-101.

SVATOS, M., MAITAH, M. and BELOVA, A. 2013. World sugar market-basic development trends and tendencies. Agris On-Line Papers in Economics and Informatics, 5(2): 73-88.

VOLLRATH, T. L. 1991. A Theoretical Evaluation of Alternative Trade Intensity Measures of Revealed Comparative Advantage. Weltwirtschaftliches Archiv-Review of World Economics, 127(2): 265-280.

VOZAROVA, I. K., KOTULIC, R. and SIRA, E. 2015. V4 countries' agricultural sector evaluation in terms of competitive advantage. Economic Annals, 21(5-6): 60-63.

WIDODO, T. 2009. Comparative Advantage: Theory, Empirical Measures and Case Studies. Review of Economic and Business Studies, 4: 57-82.

ZAGHINI, A. 2003. Trade advantages and specialization dynamics in acceding countries. ECB Working Paper No. 249. Frankfurt am Main, Germany: European central bank. 